\title{
Comparison of Expression CCD4 Gene Levels in Petals of Evergreen Azalea Species
}

\author{
Kenji Ureshino $^{1 *}$, Hiroya Takara ${ }^{1}$ and Ikuo Miyajima ${ }^{2}$ \\ ${ }^{1}$ Faculty of Agriculture, University of the Ryukyus, Nishihara, Okinawa 903-0213, Japan \\ ${ }^{2}$ Institute of Tropical Agriculture, Kyushu University, Fukuoka 819-0395, Japan
}

Intersubgeneric crosses between white-flowered evergreen azalea species and a yellow-flowered deciduous azalea (Rhododendron japonicum f. flavum) can produce yellow-flowered evergreen azaleas. The petal color of $F_{1}$ progenies from these crosses is known to fade during petal development due to a high expression of the carotenoid cleavage dioxygenase 4 ( $C C D 4$ ) gene inherited from the evergreen species. In this study, to facilitate the selection of evergreen azalea species as cross parents that have low expression levels of CCD4 in developing petals, $C C D 4$ expression levels were compared among 16 evergreen azalea species belonging to the subgenus Tsutsusi. The identity values of the deduced amino acid sequences of $C C D 4$ were high (from $97 \%$ to $100 \%$ ) among evergreen azalea species. The expression levels of $C C D 4$ genes in petals of evergreen azalea species at the day of anthesis varied widely from 2.04 to 20.47 times relative to that in $R$.japonicum f. flavum. Among these species, $R$. amanoi maintained low $C C D 4$ expression levels throughout all petal development stages that were not significantly different from those of $R$. japonicum f. flavum (JPN). This species is therefore considered a promising breeding material for producing yellow-flowered evergreen azaleas.

Key Words: CCD4, fading of petal color, Rhododendron.

\section{Introduction}

Evergreen azaleas (subgenus Tsutsusi of the genus Rhododendron) are highly popular ornamental woody plants. Cultivated varieties have been developed by natural and artificial hybridization and selection among evergreen species belonging to the subgenus Tsutsusi in the genus Rhododendron. The flower colors of cultivated varieties are mainly variations of white, pink, red, or purple. However, no yellow-flowered cultivar of evergreen azaleas has been produced to date.

Creating yellow-flowered cultivars is one of the important breeding objectives for evergreen azaleas. $R$.japonicum f.flavum is a yellow-flowered deciduous species belonging to the subgenus Pentanthera (Yamazaki, 1996). Its yellow petals contain carotenoid compounds such as $\beta$-carotene and lutein as the main pigments (Ureshino et al., 2016). To create yellow-

Received; February 6, 2019. Accepted; July 24, 2019.

First Published Online in J-STAGE on September 12, 2019.

This work was supported by a Grant-in-Aid for Scientific Research (C) (No. 16K07602) from the Japan Society for the Promotion of Science (JSPS).

* Corresponding author (E-mail: u1969930@agr.u-ryukyu.ac.jp). flowered evergreen azaleas, we conducted intersubgeneric crosses between evergreen azalea species and $R$. japonicum f.flavum, and many progenies were obtained (Ureshino et al., 1998). Although these progenies were semi-deciduous, the petal color of the buds on the progenies was light yellow just before anthesis, and these petals contained carotenoid pigments (Miyajima et al., 2000). However, the light-yellow color of the petals was not stable, and it faded as the flower developed.

In a previous report, we compared the concentration and composition of carotenoids and the expression patterns of carotenoid biosynthesis and cleavage genes during petal development in a yellow-flowered deciduous azalea (Rhododendron japonicum f.flavum), a white-flowered evergreen azalea ('Miyamasatsuki'), and their progeny, to determine the factors that cause discoloration as the petals of the progeny develop (Ureshino et al., 2016). In petals of R.japonicum f. flavum, a high expression of carotenoid biosynthetic genes and low expression of $C C D 4$ were observed, and total carotenoid concentrations were maintained during petal development. On the contrary, in white-flowered evergreen azalea, low expression levels of carotenoid biosynthetic genes and a high expression of $C C D 4$ were observed during petal development, and as a result, 
carotenoids barely accumulated in the petals. The progeny has a relatively high expression of carotenoid biosynthetic genes inherited from R.japonicum f. flavum. Carotenoid degradation in the petals of the progeny was mediated by the high $C C D 4$ gene expression inherited from white-flowered evergreen azalea. Thus, selecting evergreen azaleas that show low CCD4 expression during petal development as breeding material is useful to avoid discoloration of petals in the progenies.

Many evergreen azalea species belong to the section Tsutsusi of the subgenus Tsutsusi; the latter includes two subsections - subsect. Scabra and subsect. Tsutsusi (Yamazaki, 1996). There are 22 species in this section, and morphological traits and growth habitats vary widely among them. Therefore, there may also bevariation in $C C D 4$ expression among these species. The objective of this study was to identify the species that maintained low expression levels of $C C D 4$ in petals during flower development in 16 evergreen azalea species.

\section{Materials and Methods}

\section{CCD4 gene isolation and sequence analysis}

Plant materials are listed in Table 1. As evergreen azalea species, 26 plants of the subgenus Tsutsusi were used, in which six species belonged to the ser. Scabra subsect. Scabra, four species belonged to ser. Tsutsusi of subsect. Tsutsusi, and seven species belonged to ser. Kaempferia of subsect. Tsutsusi. For R.transiens, R. kaempferi, R. sataense, R.tosaense, and $R$. kiusianum, several different clones were used as plant material. Rhododendron japonicum f. flavum belonging to the subgenus Pentanthera was also used.

Total RNA was extracted from petals on the day of anthesis from all plants using a Nucleospin RNA Plant kit (Takara Bio Inc., Shiga, Japan), and cDNA was synthesized using a PrimeScript II Hi Fidelity RT-PCR kit

Table 1. Species and accession numbers of the $C C D 4$ genes used in this study.

\begin{tabular}{|c|c|c|c|}
\hline Taxon & Collection site & Abbreviation & Accession No \\
\hline \multicolumn{4}{|l|}{ Subgen. Pentanthera } \\
\hline R. japonicum f. flavum & Oita pref. & JPN & LC053677 \\
\hline \multicolumn{4}{|l|}{ Subgen. Tsutsusi } \\
\hline \multicolumn{4}{|l|}{ Subsect. Scabra } \\
\hline \multicolumn{4}{|l|}{ Ser. Scabra } \\
\hline R. scabrum & Iriomote Is., Okinawa pref. & SCA & LC440313 \\
\hline R. oldhamii & Taiwan & OLD & LC440317 \\
\hline R. scabrum var. yakuinsurae & Yakushima Is., Kagoshima pref. & YAK & LC440314 \\
\hline R. amanoi & Iriomote Is., Okinawa pref. & AMA & LC440315 \\
\hline$R$. ripens & Unknown & RIP & LC440318 \\
\hline R. yedoense var. yedoense f. poukhanense & Tsushima Is., Nagasaki pref. & YED & LC440316 \\
\hline \multicolumn{4}{|l|}{ Subsect. Tsutsusi } \\
\hline \multicolumn{4}{|l|}{ Ser. Tsutsusi } \\
\hline R. indicum & Yakushima Is., Kagoshima pref. & IND & LC440308 \\
\hline R. eiocarpum \#1 & Nakanoshima Is., Kagoshima pref. & ERI1 & LC440311 \\
\hline R. eiocarpum \#2 & Yakushima Is., Kagoshima pref. & ERI2 & LC440312 \\
\hline R. eiocarpum var. tawadae & Okinawa pref. & TAW & LC440309 \\
\hline R. nakaharae & Taiwan & NAK & LC440310 \\
\hline \multicolumn{4}{|l|}{ Ser. Kaempferia } \\
\hline R. simsii & Okinawa pref. & SIM & LC440304 \\
\hline R. transiens \#1 & Unknown & TRA1 & LC440306 \\
\hline R. transiens \#2 & Unknown & TRA2 & LC440307 \\
\hline R. transiens \#3 & Unknown & TRA3 & LC440305 \\
\hline R. kaempferi \#1 & Kagoshima pref. & KAE1 & LC440296 \\
\hline R. kaempferi \#2 & Saga pref. & KAE2 & LC440297 \\
\hline R. kaempferi \#3 & Kagoshima pref. & KAE3 & LC440295 \\
\hline R. sataense \#1 & Kagoshima pref. & SAT1 & LC440298 \\
\hline R. sataense \#2 & Kagoshima pref. & SAT2 & LC440299 \\
\hline R. sataense \#3 & Kagoshima pref. & SAT3 & LC440300 \\
\hline R. kaempferi var. macrogemma & Tokyo pref. & MAC & LC440301 \\
\hline R. tosaense \#1 & Miyazaki pref. & TOS1 & LC440303 \\
\hline R. tosaense \#2 & Miyazaki pref. & TOS2 & LC440302 \\
\hline R. kiusianum \#1 & Oita pref. & KIU1 & LC440293 \\
\hline R. kiusianum \#2 & Kagoshima pref. & KIU2 & LC440294 \\
\hline
\end{tabular}


(Takara Bio). To isolate coding sequences (CDS) of the carotenoid cleavage dioxygenases gene (CCD4), RTPCR was conducted using gene-specific primers (forward; 5'GGTATCAACGCAGAGTACATGG3', reverse; 5'GCCGGGACTACAAGTTTACAAC3') and cDNA from petals at stage 2. PCR amplifications were carried out in a total volume of $50 \mu \mathrm{l}$ containing $25 \mathrm{ng}$ of template cDNA, $0.5 \mu \mathrm{M}$ of each primer, $50 \mathrm{mM}$ of dNTPs, $5 \mu \mathrm{l}$ of $10 \times$ reaction buffer and 2.5 unit of TaKaRa Taq DNA HS (Takara Bio). Amplification was carried out using Program Temp Control System TP-350 (Takara Bio) with 35 cycles at $10 \mathrm{sec}$ at $98^{\circ} \mathrm{C}, 30 \mathrm{sec}$ at 58 and $2.5 \mathrm{~min}$ at $72^{\circ} \mathrm{C}$ and one cycle at $72^{\circ} \mathrm{C}$ for $5 \mathrm{~min}$. The amplified PCR products were cloned into the pMD20-T vector (Mighty TA Cloning Kit; Takara Bio), and were sequenced with a Big Dye Terminator v3.1 Cycle Sequencing Kit and an ABI PRISM 3130 Genetic Analyzer (Applied Biosystems, Foster City, CA, USA). The deduced amino acid sequences were aligned with the ClustalW program (http://www.clustal.org).

Interspecific comparison of $\mathrm{CCD} 4$ expression levels in petals at the day of anthesis using real-time PCR

Species listed in Table 1 were used except for two species, R.transiens \#1 (TRA 1) and R. ripens (RIP). These two species were excluded because their nucleotide sequences did not match the annealing sites of the designed primer (Fig. S1). Three flowers were harvested from each plant at the day of anthesis (stage 2). Total RNA was extracted from the petals of each flower as mentioned above, and cDNA was synthesized using PrimeScript RT Master Mix (Perfect Real Time) (Takara Bio). The transcript levels of the CCD4 gene were analyzed by quantitative real-time PCR (RTqPCR) using SYBR Premix Ex Taq II polymerase (Takara Bio) and a Thermal Cycler Dice Real Time System II MRQ (Takara Bio), according to the manufacturers' instructions. The primer pair for the $C C D 4$ gene was designed based on the consensus sequences from all plants used in this study (forward; 5'GCCAAG GAGCCCAATAACC3', reverse; 5'CGATTTGGCATC CATCACC3'). cDNA was synthesized using PrimeScript $^{\mathrm{TM}}$ RT Master Mix (Perfect Real Time) (Takara Bio). The reaction mixture $(25 \mu \mathrm{l})$ consisted of $12.5 \mu \mathrm{l}$ of $2 \times$ SYBR Premix Ex Taq II (Takara Bio), $0.4 \mu \mathrm{M}$ each of the forward and reverse primers, $2 \mu \mathrm{l}$ of the cDNA template (corresponding to $8 \mathrm{ng}$ of total RNA), and $8.5 \mu \mathrm{l}$ of $\mathrm{dH}_{2} \mathrm{O}$. PCR was performed using the following program: an initial denaturation of $30 \mathrm{~s}$ at $95^{\circ} \mathrm{C}$, followed by 40 cycles at $95^{\circ} \mathrm{C}$ for $5 \mathrm{~s}$ and $60^{\circ} \mathrm{C}$ for $30 \mathrm{~s}$. Amplification of the ACTIN (Nakatsuka et al., 2008), pyruvate dehydrogenase, and histone $\mathrm{H} 3$ genes (De Keyser et al., 2007) under identical conditions was conducted as an internal control to normalize the cDNA levels. Real-time PCR data were analyzed using Multiplate RQ software (Takara Bio), which can analyze multiple reference genes. Calculations by the soft- ware were based on the GeNorm manual (Vandesompele et al., 2002). From the data for each $\mathrm{PCR}$, the relative expression values of $C C D 4$ were calculated and normalized against the reference genes using standard curve methods. These experiments were conducted with three biological replicates.

\section{Observation of CCD4 expression levels during petal development}

We chose six species belonging to the subgenus Tsutsusi that included R.amanoi, R. scabrum var. yakuinsurae, R. indicum, R. eiocarpum var. tawadae, $R$. simsii, and R. kaempferi var. macrogemma, and $R$.japonicum f.flavum belonging to the subgenus Pentanthera, as plant materials. Three flowers were harvested from each plant at different stages of development. The stages were divided into 1, 2, 3, and 4, which referred to petals at one day before flowering, at the day of anthesis, at two days after anthesis, and at five days after anthesis, respectively (Fig. 1). The petals from each flower were used for RT-qPCR using the

$$
\text { Stage } 1 \quad \text { Stage } 2 \quad \text { Stage } 3 \quad \text { Stage } 4
$$

JPN

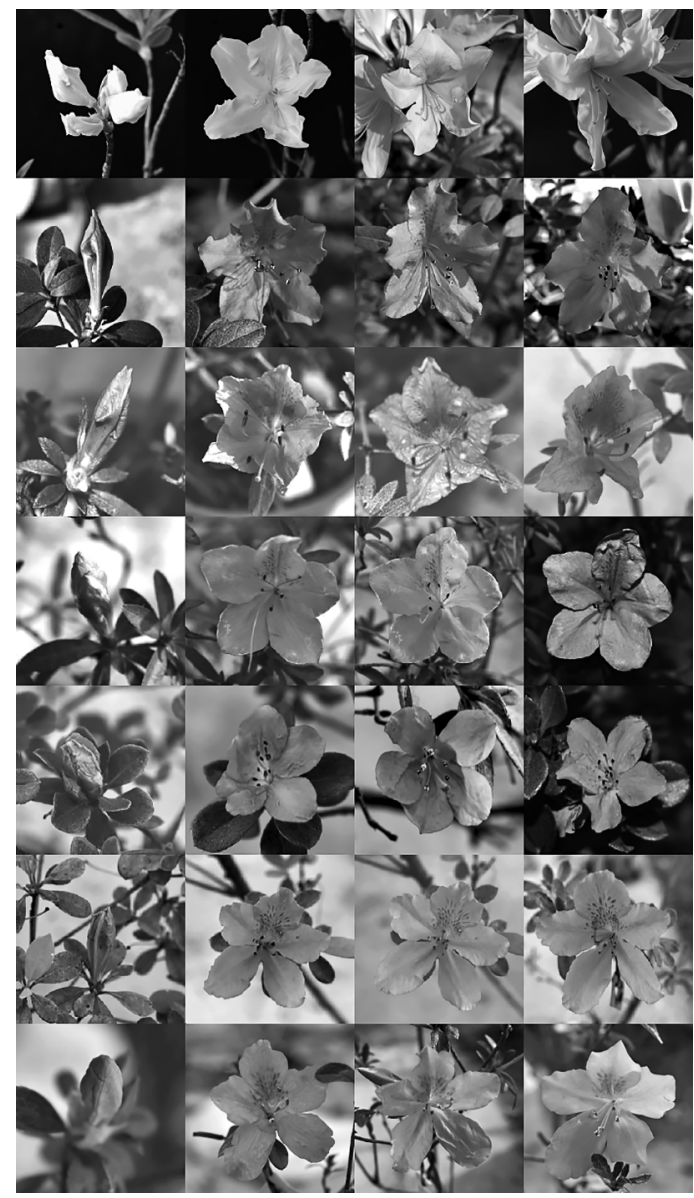

Fig. 1. Flowers of seven species at different stages. Stage1, one day before flowering; Stage 2, the day of anthesis; Stage 3, two days after anthesis; Stage 4 , five days after anthesis. 
aforementioned procedures. Three biological replicates were conducted in this experiment.

\section{Results}

\section{Sequence analysis of CCD4}

The CDS of CCD4 in evergreen azalea species, except $R$. nakaharae and $R$. eiocarpum var. tawadae, was $1803 \mathrm{bp}$ long and encoded a protein of 600 amino acids. The CDS of R. nakaharae was 1788 bp long and encoded a protein of 595 amino acids, and the CDS of R. eiocarpum var. tawadae was $1800 \mathrm{bp}$ long and encoded a protein of 599 amino acids. CCD4 genes in all species had four highly conserved histidine residues that have been previously described as typical ligands of a non-heme iron cofactor required for (di)-oxygenase activity, conserved glutamates or aspartate that are used to fix iron-ligating histidines (Kloer and Schulz, 2006), had a predicted plastid-targeting sequence in the $\mathrm{N}$ terminal region (1-35) (Fig. S2). The percent identity values of the deduced amino acid sequences of $C C D 4$ were from $95 \%$ to $96 \%$ between $R$. japonicum $\mathrm{f}$. flavum and evergreen azaleas, and from $97 \%$ to $100 \%$ among evergreen azalea species. These sequences are available in the DNA Data Bank of Japan (DDBJ). The accession numbers are listed in Table 1.

Interspecific comparison of the CCD4 gene expression levels in petals at the day of anthesis

The CCD4 gene expression levels in petals at the day of anthesis in all evergreen azalea species were higher than in R.japonicum f.flavum (JPN), which varied widely from 2.04 to 20.47 times relative to that of R. japonicum f.flavum (Fig. 2). The lowest expression level values among evergreen azaleas were 2.04 in R. amanoi (AMA), 2.31 in R. yedoense var. yedoense f. poukhanense (YED), 2.63 in R. indicum (IND), and 3.00 in R. scabrum var. yakuinsurae (YAK), respectively.

\section{Expression of $\mathrm{CCD} 4$ during petal development}

The expression pattern of $C C D 4$ during petal development differed among species (Fig. 3). In R. amanoi

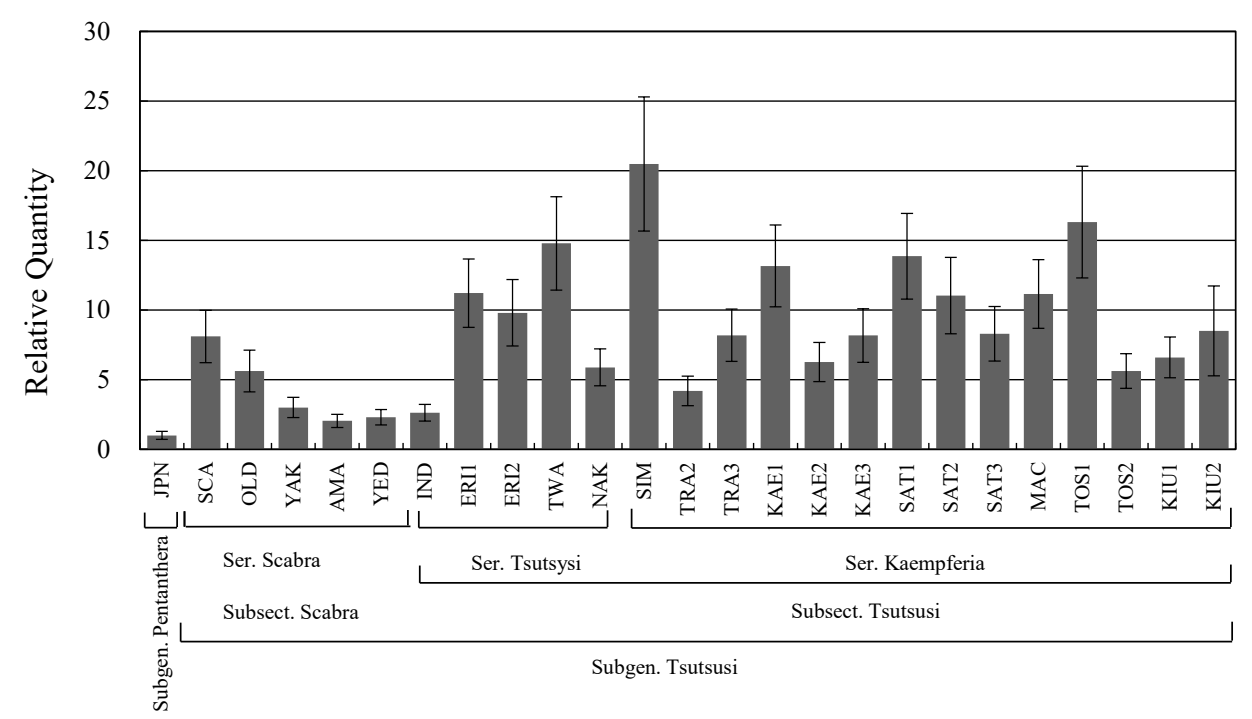

Fig. 2. Comparison of the relative expression levels of CCD4 in the petals of Rhododendron spp. on the day of anthesis. Error bars indicate SE. Abbreviations of azalea species are given in Table 1.

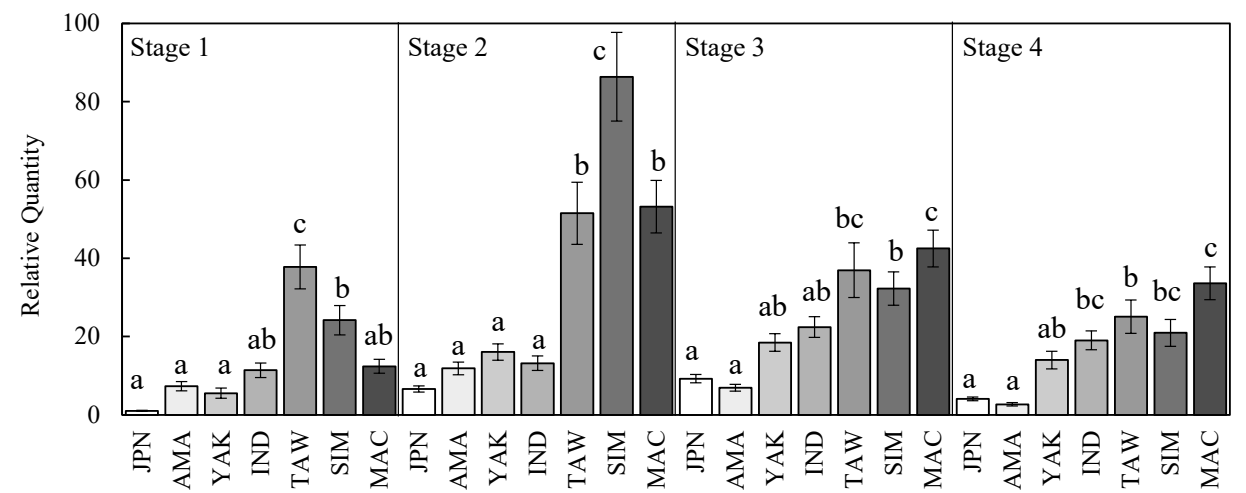

Fig. 3. Changes in the expression pattern of CCD4 during petal development. Values marked with different letters indicate statistically significant difference (Tukey's test, 5\% significance). Error bars indicate SE. Abbreviations of azalea species are given in Table 1. 
(AMA), R. eriocarpum var. tawadae (TAW), R. simsii (SIM), and R. kaempferi var. macrogemma (MAC), $C C D 4$ expression levels increased from stage 1 to stage 2 , and then decreased. In R.japonicum f.flavum (JPN), $R$. indicum (IND) and R. scabrum var. yakuinsurae (YAK), CCD4 expression levels increased from stage 1 to stage 3 , and then decreased. Compared with the low CCD4 expression levels of R.japonicum f.flavum (JPN), significantly high expression levels were observed for all stages in R. eriocarpum var. tawadae (TAW) and R. simsii (SIM), after stage 2 in R. kaempferi var. macrogemma (MAC), and at stage 4 in $R$. indicum (IND). In contrast, R. amanoi (AMA) and R. scabrum var. yakuinsurae (YAK) had low CCD4 expression levels throughout all stages; these were not significantly different from those of $R$.japonicum f. flavum (JPN). In particular, CCD4 expression levels in $R$. amanoi (AMA) were the lowest after stage 2 among six evergreen species and were lower than those of $R$. japonicum f. flavum (JPN) after stage 3.

\section{Discussion}

The contribution of $C C D 4$ to white color formation in petals by cleaving carotenoids into colorless compounds has been reported for Chrysanthemum species (Ohmiya et al., 2006) and Lilium brownii var. colchesteri (Hai et al., 2012). Carotenoids are metabolized to apocarotenoids through reactions catalyzed by $C C D$ (Kato et al., 2006). CCD4 also played a major role in causing discoloration during petal development of the progeny of the intersubgeneric cross between evergreen azalea species and $R$.japonicum f.flavum (Ureshino et al., 2016). In the present study, CCD4 was detected in various evergreen azalea species belonging to the subgenus Tsutsusi. The deduced amino acid sequences among them showed high similarity and included all amino acid residues necessary for binding to a non-heme iron cofactor (Kloer and Schulz, 2006). Based on these findings, it is considered that all CCD4 genes are functional.

It was reported that Chrysanthemum CCD4 $(\mathrm{CmCCD} 4 a)$ comprises a small gene family in the genome, and several homologs are expressed in ray petals (Yoshioka et al., 2012). In a previous report, we cloned of CCD4 at least five times to isolate the homologs in $R$.japonicum f.flavum and the white-flowered evergreen azalea 'Miyamasatsuki' (Ureshino et al., 2016). In R. japonicum f. flavum, only one sequence was obtained. In 'Miyamasatsuki', two sequences were obtained. Since 'Miyamasatsuki' is an interspecific $F_{1}$ hybrid between $R$. kiusianum and R. eriocarpum, the two sequences are considered to be allelic variations. Thus, it was considered that $C C D 4$ did not construct a gene family in azalea.

In contrast, the expression levels of $C C D 4$ genes varied widely among the evergreen azalea species. Among them, it was noteworthy that R. amanoi and
R. scabrum var. yakuinsurae, which belong to subsect. Scabra, maintained low CCD4 expression levels throughout all petal development stages, and were not significantly different to those of R.japonicum f. flavum. It is known that the structural properties of the promoter play a crucial role in gene expression (Das and Bansal, 2019). Proximal and distal regions upstream of the core promoter contain different regulatory sequences such as enhancers, silencers, insulators, and cis-elements that contribute to the fine regulation of gene expression at the transcriptional level (HernandezGarcia and Finer, 2014). In Oryza sativa, mutations such as insertions, deletions and substitutions in the promoter region caused the down-regulation of a disease resistance gene (Xa13). (Chu et al., 2006). Differences in the gene expression levels of the CCD4 gene among evergreen azalea species may be affected by such mutations in the promoter region. To clarify this point, we will isolate the promoter region of $C C D 4$ and compare the sequences among evergreen azalea species.

In the petals of $F_{1}$ progenies of the intersubgeneric crosses between evergreen azalea species and R.japonicum f.flavum, carotenoid degradation was mediated by a high $C C D 4$ gene expression inherited from evergreen azalea species (Ureshino et al., 2016). Selection of evergreen species as cross parents that have low expression levels of the CCD4 gene throughout petal development is the key to overcoming carotenoid degradation in the petals of progenies. R. amanoi is, therefore, considered to be a promising breeding material for producing yellow-flowered evergreen azaleas.

\section{Literature Cited}

Chu, Z., M. Yuan, J. Yao, X. Ge, B. Yuan, C. Xu, X. Li, B. Fu, Z. Li, J. L. Bennetzen, Q. Zhang and S. Wang. 2006. Promoter mutations of an essential gene for pollen development result in disease resistance in rice. Genes Dev. 20: 1250-1255.

Das, S. and M. Bansal. 2019. Variation of gene expression in plants is influenced by gene architecture and structural properties of promoters. Plos One. 14: e0212678. DOI: 10.1371/ journal.pone.0212678.

De Keyser, E., J. De Riek and E. Van Bockstaele. 2007. Gene expression profiling of key enzymes in azalea flower colour biosynthesis. Acta Hortic. 743: 115-120.

Hai, N. T. L., J. Masuda, I. Miyajima, N. Q. Thien, N. Mojtahedi, M. Hiramatsu, J. H. Kim and H. Okubo. 2012. Involvement of carotenoid cleavage dioxygenase 4 gene in tepal colour change in Lilium brownii var. colchesteri. J. Japan. Soc. Hort. Sci. 81: 366-373.

Hernandez-Garcia, C. M. and J. J. Finer. 2014. Identification and validation of promoters and cis-acting regulatory elements. Plant Sci. 217-218: 109-119.

Kato, M., H. Matsumoto, Y. Ikoma, H. Okuda and M. Yano. 2006. The role of carotenoid cleavage dioxygenases in the regulation of carotenoid profiles during maturation in citrus fruit. J. Exp. Bot. 57: 2153-2164.

Kloer, D. P. and G. E. Schulz. 2006. Structural and biological aspects of carotenoid cleavage. Cell Mol. Life Sci. 63: 2291-2303.

Miyajima, I., K. Ureshino, N. Kobayashi and M. Akabane. 2000. 
Flower colour and pigments of intersubgeneric hybrid between white-flowered evergreen and yellow-flowered deciduous azaleas. J. Japan. Soc. Hort. Sci. 69: 280-282.

Nakatsuka, A., D. Mizuta, Y. Kii, I. Miyajima and N. Kobayashi. 2008. Isolation and expression analysis of flavonoid biosynthesis genes in evergreen azalea. Sci. Hortic. 118: 314-320.

Ohmiya, A., S. Kishimoto, R. Aida, S. Yoshioka and K. Sumitomo. 2006. Carotenoid cleavage dioxygenase (CmCCD4a) contributes to white colour formation in chrysanthemum petals. Plant Physiol. 142: 1193-1201.

Ureshino, K., I. Miyajima and M. Akabane M. 1998. Effectiveness of three-way crossing for the breeding of yellowflowered evergreen azalea. Euphytica 104: 113-118.

Ureshino, K., M. Nakayama and I. Miyajima. 2016. Contribution made by the carotenoid cleavage dioxygenase 4 gene to yellow colour fade in azalea petals. Euphytica 207: 401-407.

Vandesompele, J., K. D. Preter, F. Pattyn, B. Poppe, N. Van Roy, A. De Paepe and F. Speleman. 2002. Accurate normalization of real-time quantitative RT-PCR data by geometric averaging of multiple internal control genes. Genome Biology 3: $1-12$.

Yamazaki, T. 1996. A revision of the genus Rhododendron in Japan, Taiwan, Korea and Sakhalin. Kokusai Bunken Insatsusha, Tokyo.

Yoshioka, S., R. Aida, C. Yamamizo, M. Shibata and A. Ohmiya. 2012. The carotenoid cleavage dioxygenase $4(\mathrm{CmCCD} 4 \mathrm{a})$ gene family encodes a key regulator of petal color mutation in chrysanthemum. Euphytica 3: 377-387. 